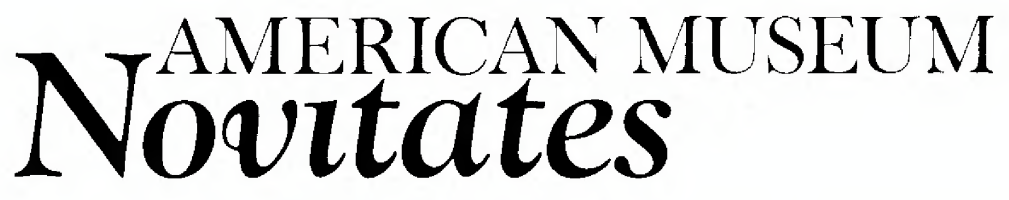

PUBLISHED BY THE AMERICAN MUSEUM OF NATURAL HISTORY
CENTRAL PARK WEST AT 79TH STREET, NEW YORK, NY 10024
Number 3313, 11 pp., 7 figures

\title{
Leeches of Laguna Volcán, Bolivia, Including a New Species of Helobdella (Clitellata: Hirudinea)
}

\author{
MARK E. SIDDALL ${ }^{1}$
}

\begin{abstract}
Three species of leeches were found in Laguna Volcán in Departmento de Santa Cruz, Bolivia. None are known to be sanguivorous. Two of the species found, Semiscolex similis and Helobdella triserialis, are known to be broadly distributed in South America. A new species, Helobdella bolivianita, is described. Diagnostic characters for this species include a nuchal scute on somite VIII and the possession both of compact salivary glands and of diffuse parenchymal salivary tissue.
\end{abstract}

\section{INTRODUCTION}

The hirudifauna of Bolivia remains essentially unstudied. Ringuelet (1953) wrote the only existing account of leeches in Bolivia based on four specimens mailed to him by Prof. Harry Marcus of the University of Cochabamba, Bolivia. Three of the four specimens were identified to species (Helobdella duplicata, Helobdella obscura, and Semiscolex similis). Later Helobdella titicacensis, originally described from Peru (Ringuelet, 1959), and other leeches were listed among faunistic samples taken from Lake Titicaca
(Dejoux, 1992), but exclusively from the Lago Grande on the Peruvian side.

From September through November of 1999, the Center for Biodiversity and Conservation of the American Museum of Natural History conducted faunistic surveys in the high Andean portion of Bolivia in collaboration with Collección Boliviana de Fauna, La $\mathrm{Paz}$, and another small excursion for aquatic invertebrates in the lowland under the auspices of the Museo de Historia Natural NoelKempff Mercado. This study details findings from the latter and constitutes only the second account of leeches in Bolivia.

\footnotetext{
${ }^{1}$ Assistant Curator, Division of Invertebrate Zoology, American Museum of Natural History.
} 


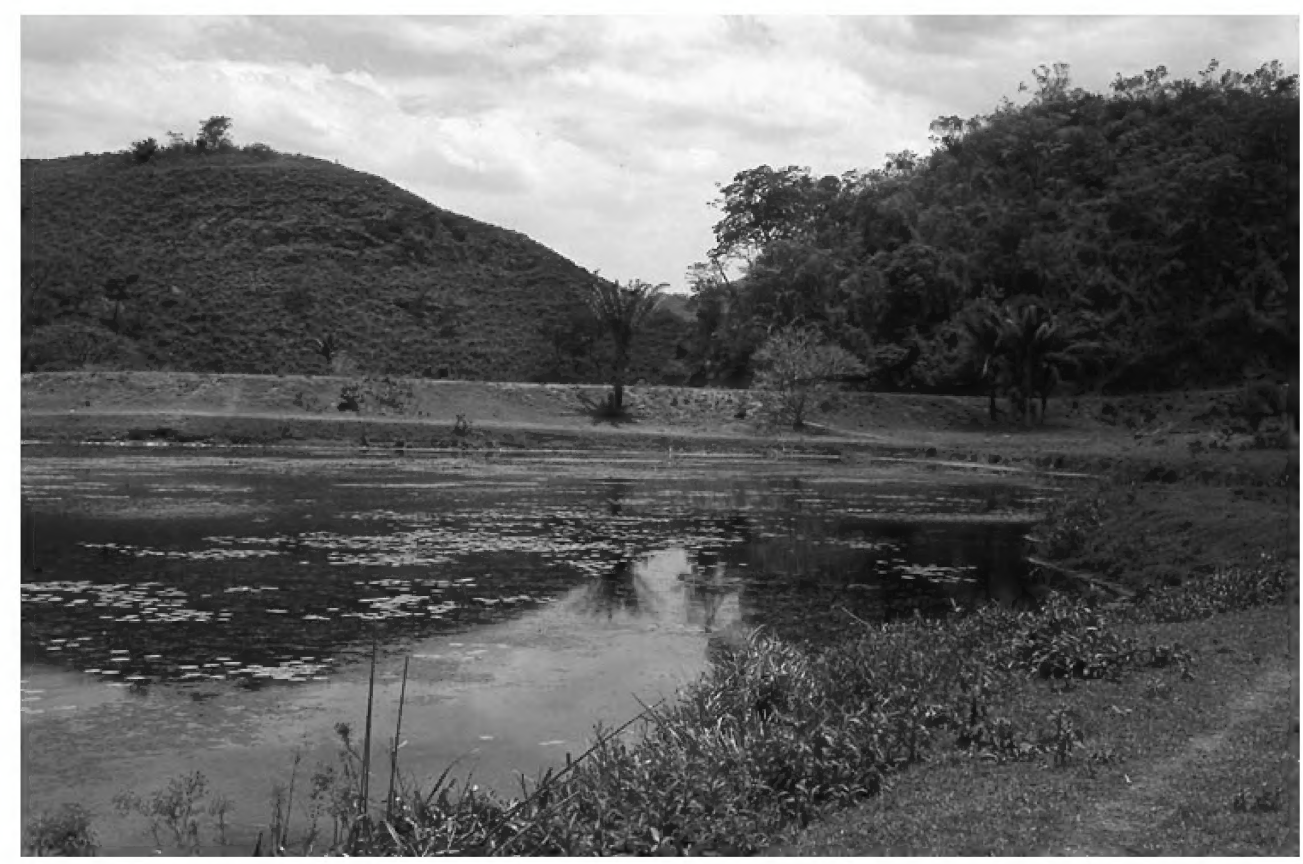

Fig. 1. Laguna Volcán, Departmento Santa Cruz, Bolivia.

\section{MATERIALS AND METHODS}

Leeches were collected in Laguna Volcán (fig. 1), Departmento de Santa Cruz, Bolivia $\left(18^{\circ} 07^{\prime} 17^{\prime \prime} \mathrm{S}, 63^{\circ} 38^{\prime} 88^{\prime \prime} \mathrm{W}\right)$ on November 14 , 1999. Laguna Volcán is situated in red sandstone foothills of the Bolivian Andes (1100 $\mathrm{m})$ and is part of the Rio Grande drainage. Despite its name, it is not a caldera lake and is not in a geologically active area. Leeches found attached to submerged stems of aquatic plants, and on the underside of submerged branches along the shoreline of the lake were relaxed with the gradual addition of $50 \%$ ethanol and fixed either in $95 \%$ ethanol or in $10 \%$ formalin.

Examination of external morphology and dissections were accomplished with a Nikon SMZ-U stereo microscope with a SPOT-RT digital camera. Specimens prepared for histology were dehydrated through ethanol, cleared with Hemo-D, and infiltrated with Paraplast Plus in a Tissue Tek II tissue processor. Longitudinal sections $(5 \mu \mathrm{m})$ were stained with Haematoxylin and Eosin/Phloxine and examined with an Olympus BX50 compound microscope at low power.

\section{ORDER ARHYNCHOBDELLIDA} BLANCHARD, 1894

\section{SUBORDER HIRUDINIFORMES} CABALLERO, 1952

FAMILY HIRUDINIDAE WHITMAN, 1886

SUBFAMILY SEMISCOLESCINAE (SCRIBAN AND AUTRUM, 1934)

Semiscolex similis (Weyenbergh, 1879)

Figure 2

MATERIAl EXAmined: Free-living from Laguna Volcán, Departmento de Santa Cruz, Bolivia, $18^{\circ} 07^{\prime} 17^{\prime \prime} \mathrm{S}, 63^{\circ} 38^{\prime} 88^{\prime \prime} \mathrm{W}, 14$ November 1999 , hand collected by M. Siddall and C. Specht; determination by M. Siddall. One specimen fixed in $10 \%$ formalin, stored in $70 \%$ ethanol (AMNH 4220, Annelida); one specimen fixed in $10 \%$ formalin, stored in $70 \%$ ethanol (Museo de Historia Natural Noel-Kempff Mercado, Santa Cruz, Bolivia, uncataloged); one specimen fixed and stored in $95 \%$ ethanol (AMNH 4221, Annelida); one specimen fixed and stored in $95 \%$ ethanol (Museo de Historia Natural Noel-Kempff Mercado, Santa Cruz, Bolivia, uncataloged); one specimen fixed and stored in $95 \%$ etha- 

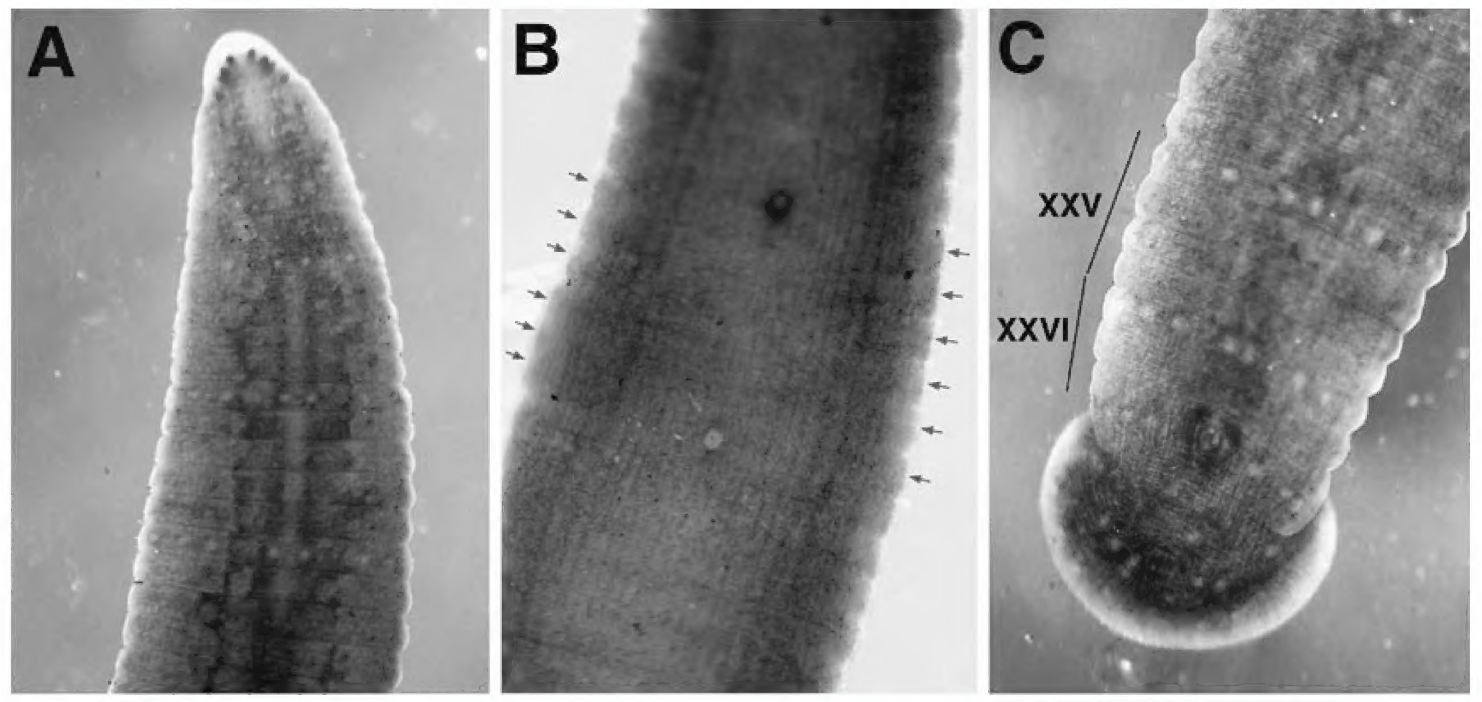

Fig. 2. Semiscolex similis. (A) Anterior somites with eyes dorsally in II, III, IV, V and VII. (B) Genital region with six annuli (arrows) ventrally between male and female gonopores. (C) Posterior somites showing four annuli, three annuli, and one annulus respectively for somites XXV, XXVI, and XXVII

nol held at $-80^{\circ} \mathrm{C}$ (AMNH 100016 , Frozen Tissue Collection). The separation of male and female gonopores by six annuli, presence of five pairs of eyes (on II, III, IV, V, and VII), somites XXV quadrianulate, XXVI trianulate, and XXVII uniannulate, all are consistent with descriptions for this species (Weyenbergh, 1879; Cordero, 1937a, 1937b; Ringuelet, 1944a, 1944b).

\section{ORDER RHYNCHOBDELLIDA BLANCHARD, 1894}

FAMILY GLOSSIPHONIIDAE VAILLANT, 1890

Helobdella triserialis (Blanchard, 1849) Figure 3

MATERIAL EXAMINED: Free-living from Laguna Volcán, Departmento de Santa Cruz, Bolivia, $18^{\circ} 07^{\prime} 17^{\prime \prime} \mathrm{S}, 63^{\circ} 38^{\prime} 88^{\prime \prime} \mathrm{W}, 14 \mathrm{No}-$ vember 1999 , hand collected by M. Siddall and C. Specht; determination by M. Siddall; four specimens fixed in $10 \%$ formalin, stored in $70 \%$ ethanol (AMNH 4222, Annelida); five specimens fixed in $10 \%$ formalin, stored in $70 \%$ ethanol (Museo de Historia Natural Noel-Kempff Mercado, Santa Cruz, Bolivia, uncataloged); five specimens fixed and stored in 95\% ethanol (AMNH 4223, Annelida); five specimens fixed and stored in $95 \%$ ethanol (Museo de Historia Natural Noel-
Kempff Mercado, Santa Cruz, Bolivia, uncataloged); one specimen fixed and stored in $95 \%$ ethanol held at $-80^{\circ} \mathrm{C}$ (AMNH 100020 , Frozen Tissue Collection). The annulation, absence of nuchal glands and presence of three rows of black tipped papillae are consistent with descriptions of this highly variable pan-American species (Blanchard, 1849; Blanchard,1896; Weber, 1915; Cordero, 1937a, 1937b; Ringuelet, 1943, 1944a, 1944b; Klemm, 1982).

\section{Helobdella bolivianita, new species}

Figures 4-7

Holotype (fig. 4): Free-living from Laguna Volcán, Departmento de Santa Cruz, Bolivia, $18^{\circ} 07^{\prime} 17^{\prime \prime} \mathrm{S}, 63^{\circ} 38^{\prime} 88^{\prime \prime} \mathrm{W}, 14$ November 1999, hand collected M. Siddall and C. Specht; (deposited in Museo de Historia Natural Noel-Kempff Mercado, Santa Cruz, Bolivia, uncataloged); body length $15.4 \mathrm{~mm}$, maximal width $2.6 \mathrm{~mm}$, fixed in $10 \%$ formalin, stored in $70 \%$ ethanol.

PARATYPES: Free-living from Laguna Volcán, Departmento de Santa Cruz, Bolivia, $18^{\circ} 07^{\prime} 17^{\prime \prime} \mathrm{S}, 63^{\circ} 38^{\prime} 88^{\prime \prime} \mathrm{W}, 14$ November 1999, hand collected M. Siddall and C. Specht. Six mature specimens and $10 \mathrm{im}-$ mature fixed in $10 \%$ formalin, stored in $70 \%$ 


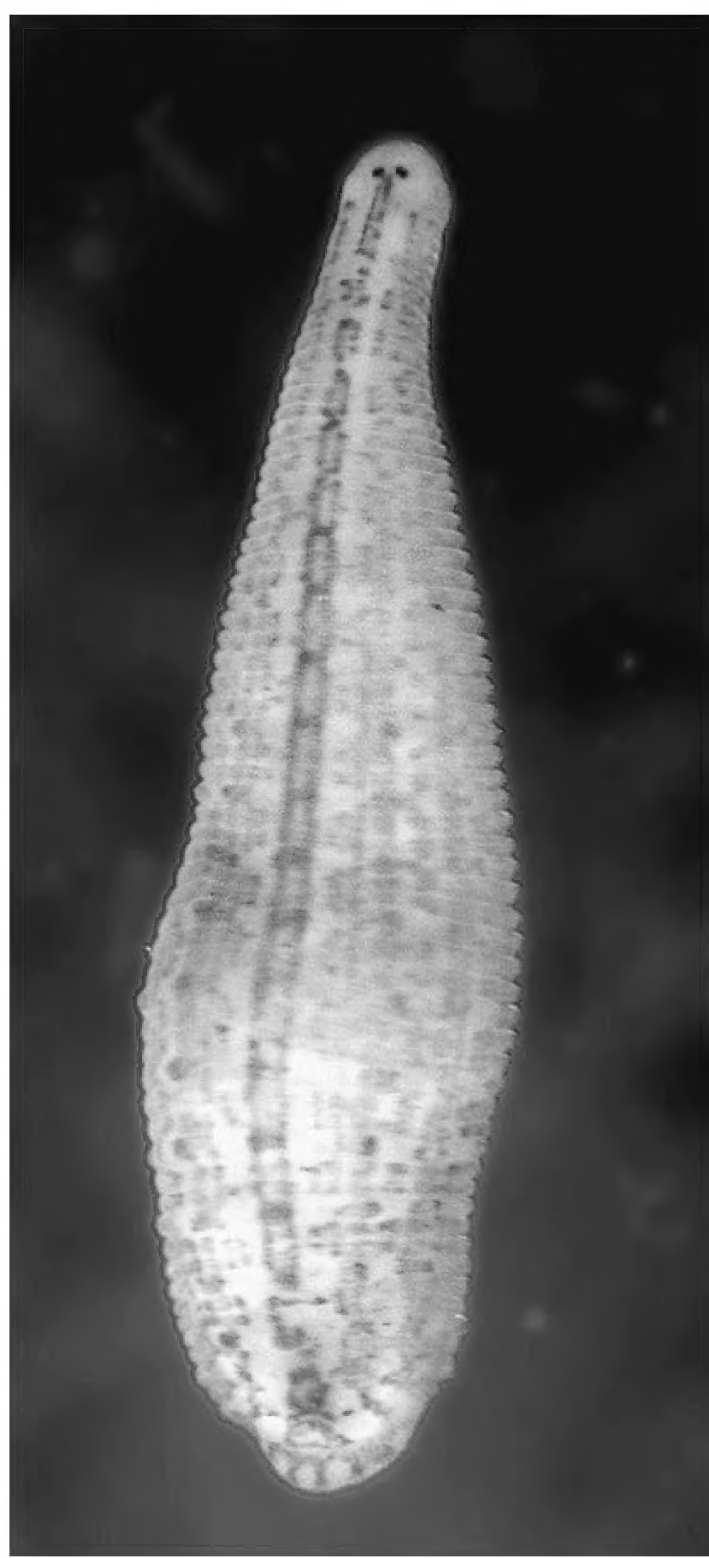

Fig. 3. Helobdella triserialis exhibiting stereotypical three longitudinal rows of black-tipped papillae.

ethanol (AMNH 4224, Annelida); one mature cleared in Hemo-D (AMNH 4225, Annelida); one dissected sexually mature, fixed in $10 \%$ formalin, stored in $70 \%$ ethanol (AMNH 4226, Annelida); one sectioned sexually mature, fixed in $10 \%$ formalin, mounted on 22 glass slides (AMNH 4227.1 through 4227.22, Annelida); seven sexually mature and 11 immature specimens fixed in $10 \%$ formalin, stored in $70 \%$ ethanol (Museo de Historia Natural Noel-Kempff Mercado, Santa Cruz, Bolivia, uncataloged); one sexually mature fixed and stored in $95 \%$ ethanol held at $-80^{\circ} \mathrm{C}$ (AMNH 100009 , Frozen Tissue Collection); six mature specimens and six juveniles fixed and stored in $95 \%$ ethanol (AMNH 4228); seven mature specimens and six juveniles fixed and stored in $95 \%$ ethanol (Museo de Historia Natural Noel-Kempff Mercado, Santa Cruz, Bolivia, uncataloged).

ETYMOLOGY: Name refers to the combined violet and yellow appearance of this leech in the living state, which resembles a composite mineral, Bolivianite (or ametrine), a combination of amethyst and citrine unique to eastern Bolivia.

DiAGNOSIS: This species is distinguished from other scutiferous species of the genus by having paired salivary glands at the base of the proboscis as well as diffuse salivary tissue in the parenchyma, subdivided annuli, six pairs of gastric caeca including diverticula, and six pairs of testisacs.

FORM (fig. 4): Body lanceolate, broadest in posterior half; somites I through IV forming somewhat broadened head region; dorsum convex, with inconspicuous papillae in some; venter flat to slightly concave, without papillae; anterior sucker oval; mouth pore subterminal; caudal sucker circular, concave, directed ventrad, diameter smaller than width of posterior somites; middorsal nuchal glands and scute in VIIIa1/a2.

EYES (fig. 4): One pair, punctiform to triangular, at junction of III and IV.

AnNulation (fig. 4): Somites I and II uniannulate; III and IV biannulate; V through XXIV triannulate each annulus subdivided; XXV and XXVI biannulate and subdivided, XVII uniannulate but no distinction from caudal sucker middorsally.

COLOR AND PATTERn (fig. 4): When alive, anterior one-third of body appearing violet blending to yellow posteriad; chromatophores arranged in approximately 30 faint longitudinal arrays dorsally, and approximately 20 faint longitudinal arrays ventrally; dorsally one pair of solid paramedial lines from IV to XXIII or XXIV, becoming intermittent more posteriorly, a second pair of lines, fainter and more lateral from VII 

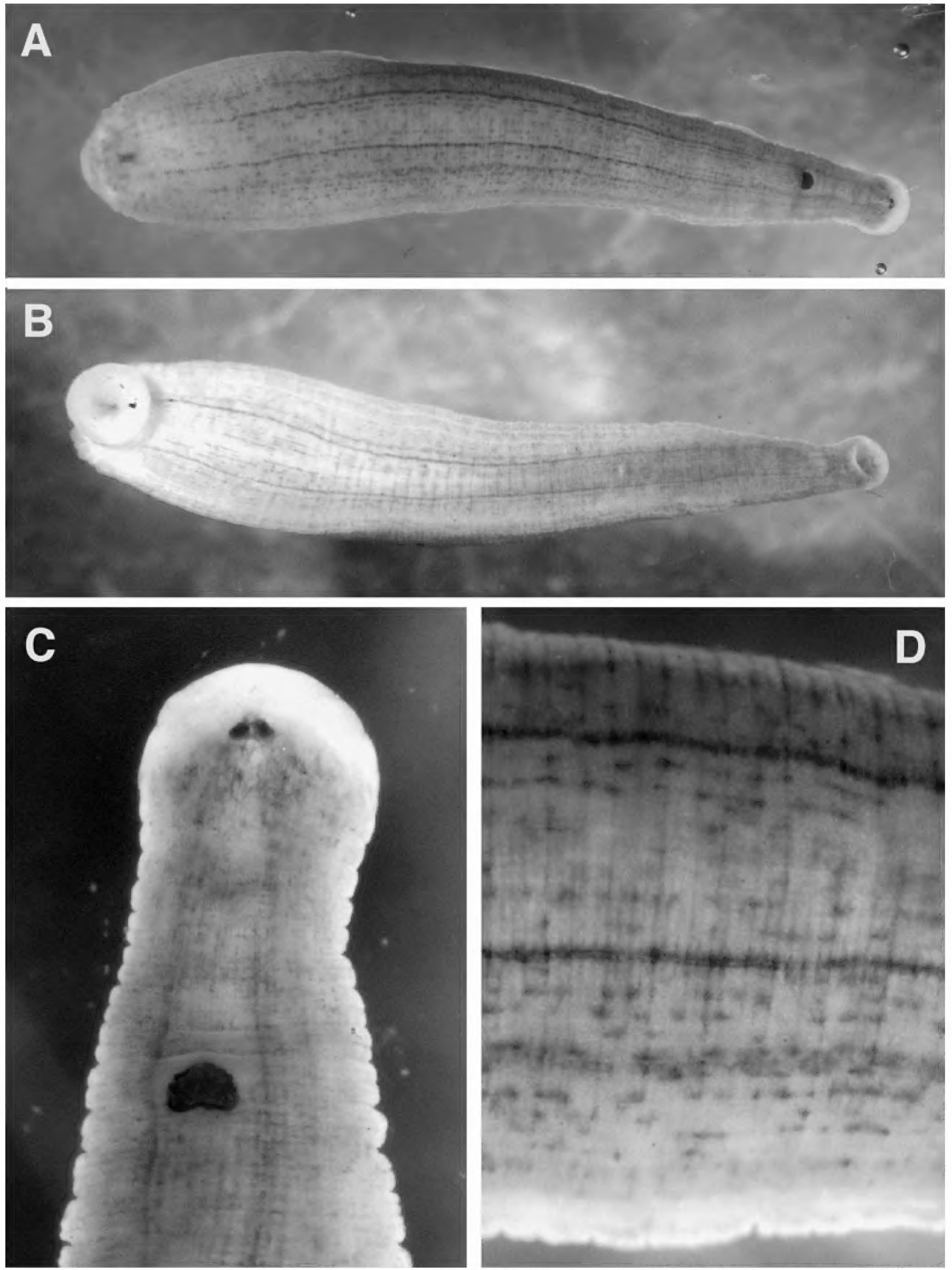

Fig. 4. Holotype of Helobdella bolivianita (A) dorsal view, (B) ventral view, (C) anterior somites with middorsal nuchal scute on VIII, and (D) midbody somites showing typical dorsal pigmentation. 


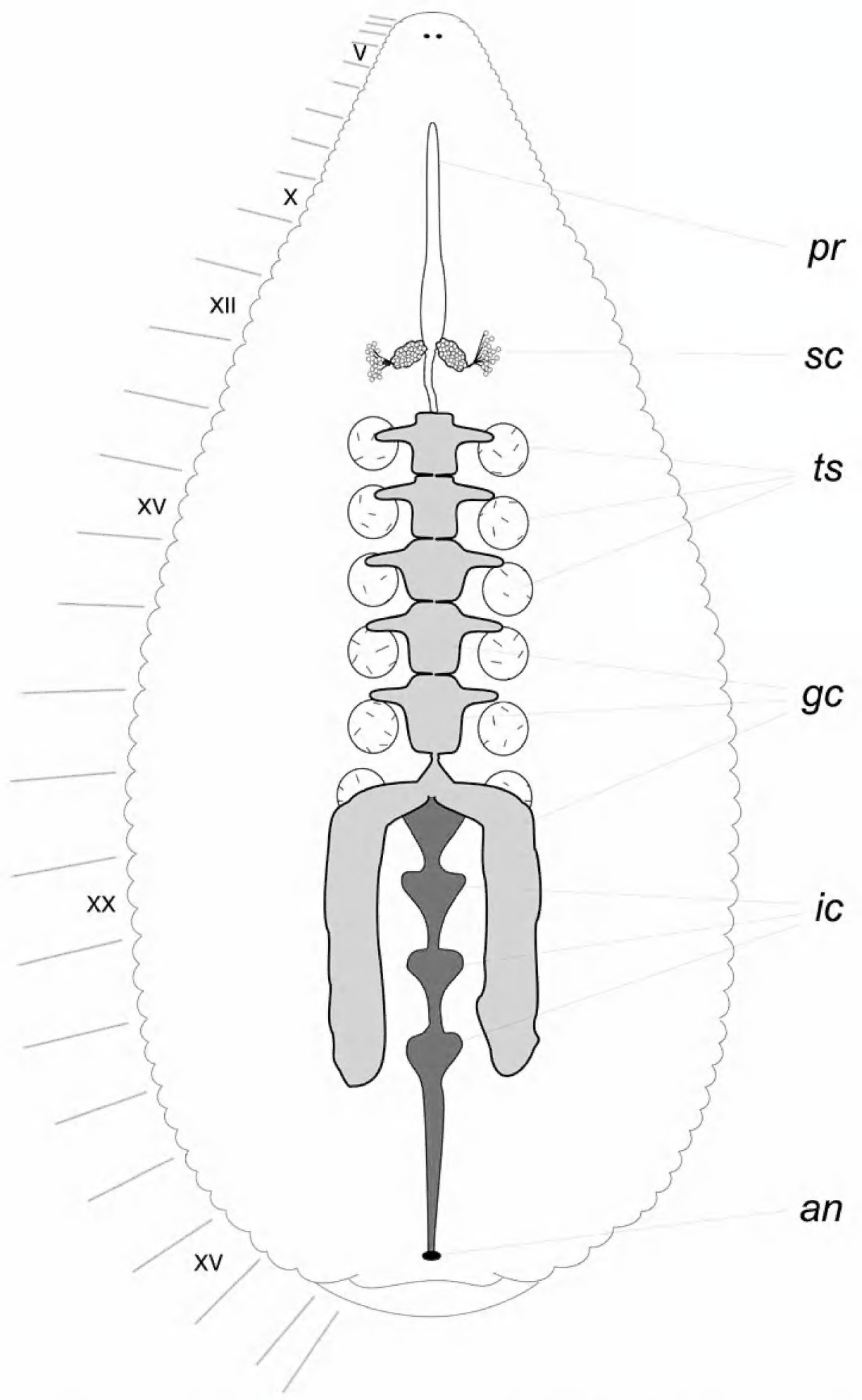

Fig. 5. Diagram of internal anatomy of Helobdella bolivianita illustrating the relative position and shape of the proboscis (pr), salivary cells (sc), testisacs (ts), gastric caeca (gc), intestinal caeca (ic), and anus (an). 


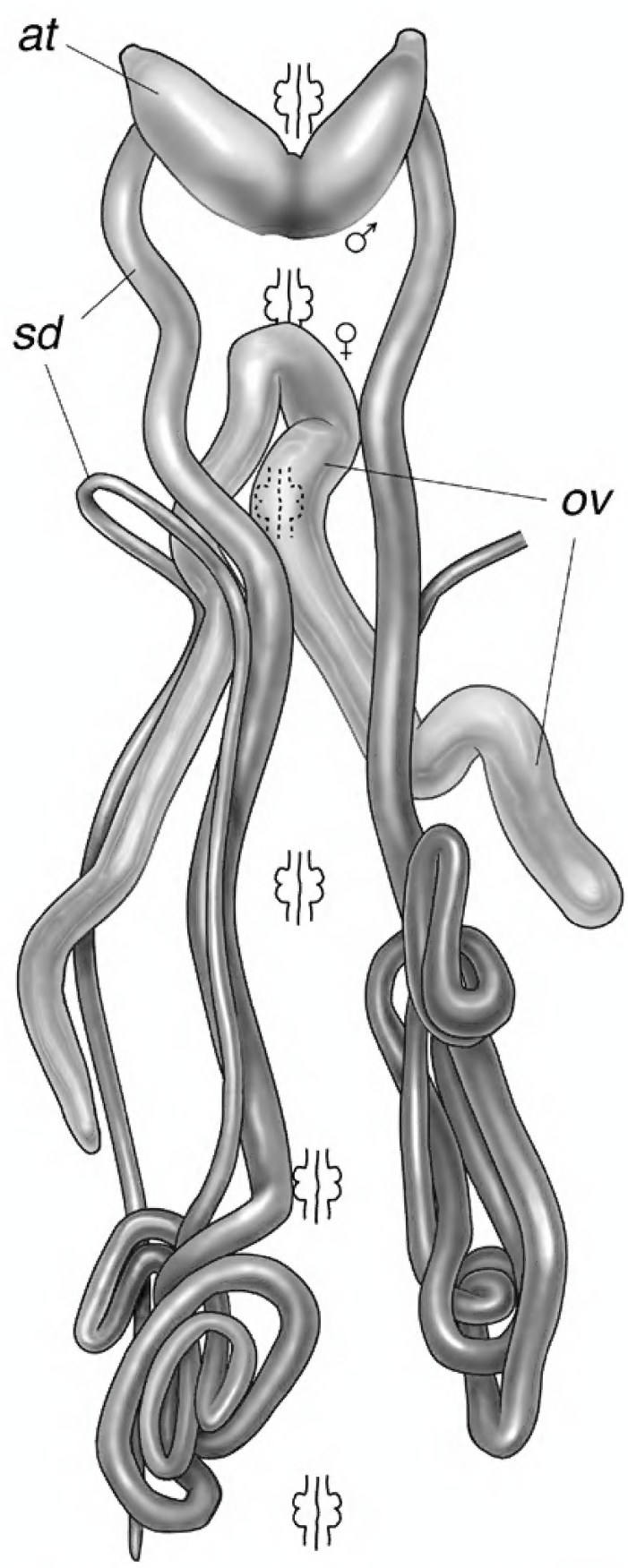

Fig. 6. Median reproductive anatomy of $\mathrm{He}$ lobdella bolivianita relative to somatic ganglia XI through XVI. Abbreviations: at, atrium; sd, sperm duct; ov, ovary. through XXIII, supramarginal lines fainter; ventrally two pairs of paramedial lines, the innermost being stronger. Anterior margin of oral sucker (I, II) considerably less pigmented than midbody somites.

ReProductive System (figs. 5, 6): Male and female gonopores separated by one annulus, male at XII a1/a2, female at XII a2/ a3; six pairs of testisacs visible histologically at XIII/XIV through XVIII/XIX; sperm ducts exit parenchyma in XIII, extend posteriad to XVI, and fold back to XV or XIV such that if unfolded would reach XVI before returning anteriad, sperm ducts empty into atria anterioventrally without preatrial loops; atria piriform approximately at $45^{\circ}$ to midline; ovisacs robust but simple, extending to $\mathrm{XV}$.

Alimentary Tract (figs. 5, 7): Proboscis slightly thicker at base than tip, in membranous sheath, base of proboscis at XII in relaxed state; salivary cells arranged both as a pair of glandular masses at base of proboscis and diffusely in parenchyma, ductules of the latter forming a bundle inserting into the former, oesophagus simple, not recurved; gastric chambers with digitiform caeca, six including postcaeca (diverticula), first five in XIV through XVII, postcaeca from XIX through XXIII or XXIV; intestine from XIX/ $\mathrm{XX}$, four lobes but not pronouncedly caecate; anus at XXVI/XXVII.

REMARKS: No other scutiferous species of leech is known to possess both compact salivary glands and diffuse salivary tissue. The presence of a nuchal scute on VIII is a clear synapomorphy (Light and Siddall, 1999) for a subset of species in the genus Helobdella, indicating that $H$. bolivianita is allied with the type species of the genus, Helobdella stagnalis (L.). In South America there are 11 known scutiferous species, most of which can be readily distinguished from $\mathrm{H}$. bolivianita. Although Adaetobdella xenoica (Ringuelet, 1975) Sawyer, 1986, has compact salivary glands, six pairs of testisacs and a scute on VIII, it has seven crop chambers, a preatrial loop for each sperm duct, and no posterior crop diverticula and does not exhibit subdivided annuli (Ringuelet, 1975, 1978b). The most broadly distributed species of scutiferous leech in South America is $\mathrm{He}$ lobdella scutifera Blanchard, 1900, known from as far south as Tierra del Fuego 


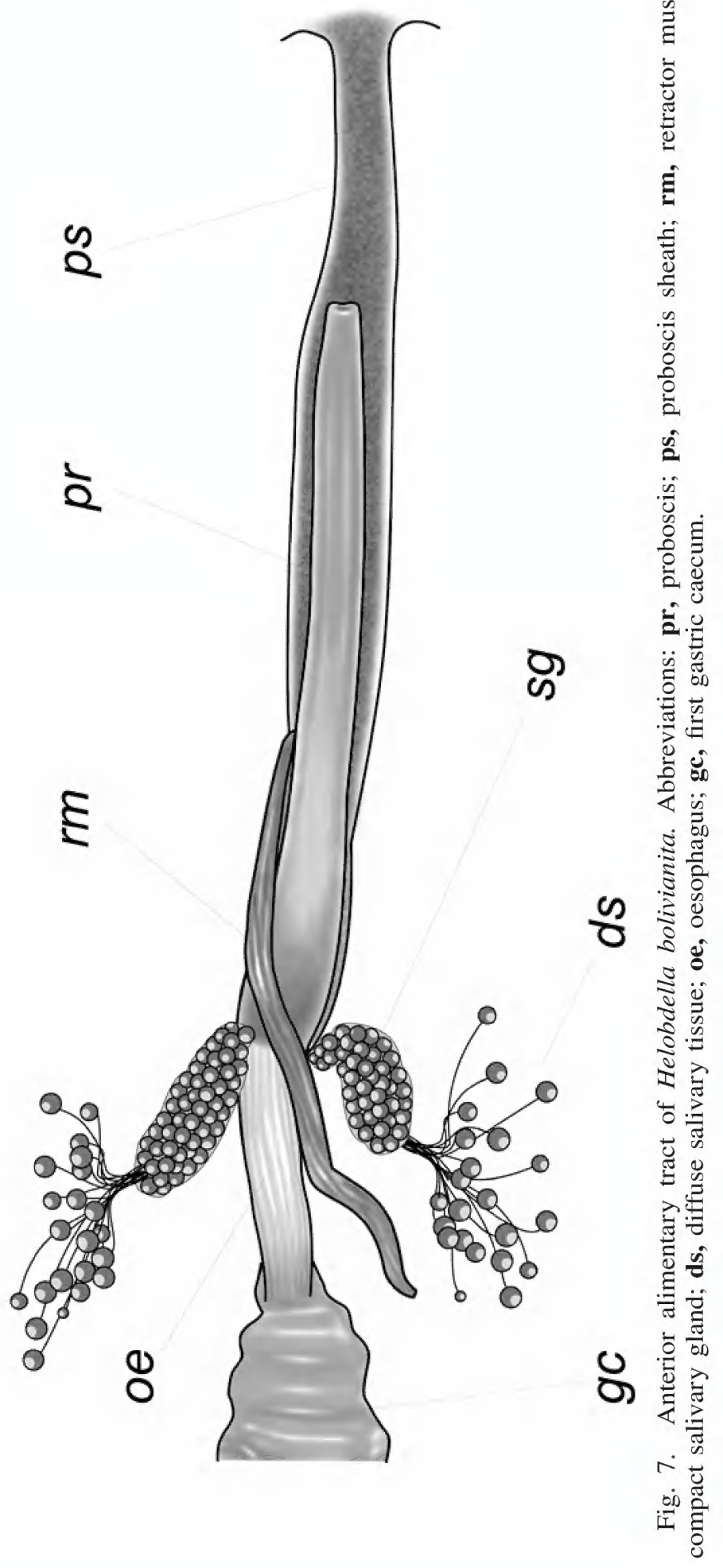


(Moore, 1911) and as far North as Rio Grande do Norte, Brazil (Cordero, 1937a). Blanchard (1900) noted dorsal paramedial lines in some individuals of $H$. scutifera reminiscent of Glossiphonia complanata and superficially similar to those described here for $H$. bolivianita. However, H. scutifera has salivary cells diffusely arranged in the parenchyma, a very long proboscis extending to and folding back anteriorly at XIV, ovaries only as long as XIV, and sperm ducts that reach XIX (Blanchard, 1900; Weber, 1915; Ringuelet, 1978a). Helobdella diploides Ringuelet, 1948, although it lacks any observable pigmentation, exhibits subdivided annuli from VII through XXV and a scute in VIII similar to $H$. bolivianita. Otherwise it is unique in having exceedingly short sperm ducts, recurving anteriorly at XIV, and atria that are distinctly at right angles to the midline (Ringuelet, 1948). Helobdella godeti Weber, 1916, Helobdella simplex Moore, 1911, and Helobdella montevidensis Cordero, 1937, though scutiferous, do not have subdivided annuli and each has obvious dorsal papillation. The most similar species and one that individuals of $H$. bolivianita may previously have been confused with is $\mathrm{He}$ lobdella duplicata Moore, 1911, originally described from Patagonia but now attributed to a broader South American distribution. Helobdella duplicata has subdivided annuli, six pairs of gastric caeca including postcaeca, six pairs of testisacs, a scute in VIII, and a caudal sucker directed strongly ventrad (Moore, 1911). However, numerous features distinguish $H$. duplicata from $H$. bolivianita, most notably a lack of compact salivary glands, a transverse metameric pigmentation on annulus a1 of each somite, globular atria with anteriodorsal insertion of spermducts, ovaries that reach XVII, and the presence of pronounced lateral caeca of the intestine (Moore, 1911).

\section{DISCUSSION}

Ringuelet's (1953) note, the only preexisting taxonomic account of leeches from Bolivia, recorded the existence of Helobdella duplicata, Helobdella obscura and an undescribed Helobdella species in samples sent from Cochabamba. His description of the specimen attributed by him to $H$. duplicata details only external morphology and does not note the strongly metameric pigment pattern otherwise characteristic of this species (Moore, 1911). In later work (Ringuelet, 1944b) the characteristics attributed to $H$. $d u$ plicata, "Color liso, con los annilos a3 más pigmentados, o liso con 2 estrías dorso-longitudinales" were not completely in accord with Moore's (1911) description of $H$. duplicata. Moore (1911) noted two broad and faint paramedial bands of pigmentation but at six muscle bundles wide they were in no sense distinct longitudinal lines on the dorsum like those of $H$. bolivianita. Eventually Ringuelet (1985) appears only to have required subdivided annuli and a scute for inclusion in $H$. duplicata, thus obviating the need for dissection. As such, it is quite possible that the one specimen from Cochabamba, Bolivia, was not $H$. duplicata. Whether or not it was Helobdella bolivianita cannot be determined from the information provided (Ringuelet, 1953). The presence in Bolivia of the other two species noted here is unremarkable. One individual of Semiscolex similis also was among the leeches detailed by Ringuelet (1953) from Cochabamba, and $\mathrm{He}$ lobdella triserialis is found from Concepción, Chile (Weber, 1915) through Northern Michigan, USA (Klemm, 1982).

The presence both of compact salivary glands at the base of the proboscis and of diffuse parenchymal salivary tissue in Helobdella bolivianita is unprecedented in Hirudinea. Two principle clades of leeches exhibit the derived condition of compact salivary glands (Light and Siddall, 1999): a monophyletic subset of Placobdella species and the genus Haementeria. Although not included in current phylogenetic assessments of the Glossiphoniidae (see Light and Siddall, 1999), the genus Adaetobdella Ringuelet, 1978 comprises species previously in the genus Helobdella but which lack parenchymal salivary tissue and possess a pair of compact salivary glands set-off from the base of the proboscis by their bundled salivary ductules (Ringuelet, 1978b). Because the genus Haementeria currently is supported as sister taxon to Helobdella, it may have been reasonable to conclude that the presence of compact salivary glands is a synapomorphy for the 
genera Haementeria and Adaetobdella. However, the existence of both kinds of salivary tissue in the scutiferous $H$. bolivianita, and only compact tissue in another scutiferous species, Adaetobdella xenoica, puts those characters in conflict. Because the type species of the genus, Helobdella stagnalis, has a scute, retaining scutiferous species in the genus Helobdella would seem to be prudent.

\section{ACKNOWLEDGMENTS}

I thank the Center for Biodiversity and Conservation of the American Museum of Natural History for funding and coordinating this expedition. The collegiality and generosity of Maria-Esther Montaño of the Museo de Historia Natural Noel-Kempff Mercado, Santa Cruz, Bolivia facilitated collection and exit of specimens. I thank Chelsea Siddall for her expertise as field guide and chauffeur as well as for her assistance with the collecting. Paula Mikkelsen kindly made available resources and knowledge in her histology laboratory. I thank Marie Lawrence for her thorough histological and curatorial work, as well as Steve Thurston for skillfully illustrating the internal anatomy of the new species.

\section{REFERENCES}

Blanchard, E.

1849. Annelides. In Gay, Historia fisca y politica de Chile. Zoologia, Paris 3: 43-50.

Blanchard, R.

1896. Viaggio del Dott. A. Borelli nella Republica Argentina e nel Paraguay. XXI. Hirudinees. Boll. Mus. Zool. Anat. Torino. 11: 1-24.

1900. Hirudineen. In Hamburger Magalhaensische Sammelreise: 1-20. Hamburg.

Cordero, E. H.

1937a. Los hirudíneos del Nordeste del Brasil, I. Especies recogidas por Clemente Pereira en 1933 y por el autor en 1935. An. Acad. Brasileira Sci. 9: 13-26.

1937b. Hirudíneos neotropicales y subantarticos. Nuevos, críticos o ya conocidos del Museo Argentino de Ciencias Naturales. An. Mus. Argentino Cienc. Nat. 39: 1-78.

Dejoux, C.

1992. The Triclada and Hirudinea. In C. Dejoux and A. Iltis (eds.), Lake TiticacaA synthesis of limnological knowledge:
307-310. Dordrecht, The Netherlands: Kluwer.

Klemm, D. J.

1982. The leeches (Annelida: Hirudinea) of North America. Aquatic Biology Section, Environmental Monitoring and Support Laboratory, Office of Research and Development, U.S. Environmental Protection Agency. Cinn., Ohio 45268.

Light, J. E., and M. E. Siddall

1999. Phylogeny of the leech family Glossiphoniidae based on mitochondrial gene sequences and morphological data. J. Parasitol. 85: 813-823.

Moore, J. P.

1911. Hirudinea of Southern Patagonia. Rep. Princeton Univ. Exped. Patagonia, 1896-1899. 3: 669-689.

Ringuelet, R. A.

1943. Sobre la morphología y variabilidad de Helobdella triserialis (Em. Bl.) (Hirudinea, Glossiphoniidae). Notas Mus. La Plata 8: 215-240.

1944a. Synopsis sistemática y zoogográfica de los hirudíneos de la Argentina, Brasil, Chile, Paraguay y Uruguay. Rev. Mus. La Plata 3: 163-232.

1944b. Los hirudíneos Argentinos de los géneros Helobdella R. B1., Batracobdella Vig., Cylicobdella Gr. y Semiscolex Kinb. Rev. Mus. La Plata 4: 5-94.

1948. Notas sobre hirudíneos neotropicales. V. Especies de la republica del Paraguay. Notas Mus. La Plata 8: $213-$ 244.

1953. Notas sobre hirudíneos neotropicales. VIII. Algunas especies de Bolivia y Perú. Notas Mu. Nacional Ciudad Eva Perón. 16: 215-224.

1959. Una colección de hirudíneos del Perú. I. Sanguijuelas del lago Titicaca. Physis 21: 187-199.

1975. Un nuevo hirudineo de Columbia parasito de la trucha arco iris. Neotropica 21: $1-4$.

1978a. Hirudineos nuevos o ya descriptos de la Argentina y del Uruguay. Limnobios 1: 258-268.

1978b. Nuevos generos y especies de Glossiphoniidae Sudamericanos basados en characteres ecto y endosomaticos (Hirudinea Glosiphoniiformes). Limnobios 1: 269-276.

1985. Synopsis de los hirudineos de Chile (Annelida). Bol. Soc. Biol. Concepción, Chile 56: 163-179. 
Weber, $\mathbf{M}$.

1915. Monographie des hirudinées SudAmericaines. Thèse por Docteur èsSciences. Université de Neuchatel. Neuchatel, France.
Weyenbergh, $\mathrm{H}$.

1879. Alguns nuevas sanguijuelas o chancacas de la familia Gnathobdellida y revista de esta familia. Bol. Acad. Nac. Cienc. Rep. Argentina, Cordoba 3: 231-244. 
Recent issues of the Novitates may be purchased from the Museum. Lists of back issues of the Novitates and Bulletin published during the last five years are available at World Wide Web site http://nimidi.amnh.org. Or address mail orders to: American Museum of Natural History Library, Central Park West at 79th St., New York, NY 10024. TEL: (212) 769-5545. FAX: (212) 7695009. E-MAIL: scipubs@amnh.org

(2) This paper meets the requirements of ANSI/NISO Z39.48-1992 (Permanence of Paper). 